\title{
Looking back, moving forward: Understanding the HIV risk and sexual health needs of men who have sex with men, Horizons studies 2001 to 2008
}

\author{
Scott Geibel \\ Population Council \\ Waimar Tun \\ Population Council \\ Placide Tapsoba \\ Population Council \\ Scott E. Kellerman \\ Population Council
}

Follow this and additional works at: https://knowledgecommons.popcouncil.org/departments_sbsr-hiv

Part of the Demography, Population, and Ecology Commons, Family, Life Course, and Society

Commons, International Public Health Commons, and the Medicine and Health Commons

How does access to this work benefit you? Let us know!

\author{
Recommended Citation \\ Geibel, Scott, Waimar Tun, Placide Tapsoba, and Scott E. Kellerman. 2010. "Looking back, moving \\ forward: Understanding the HIV risk and sexual health needs of men who have sex with men, Horizons \\ studies 2001 to 2008," Horizons Synthesis Background Papers. Washington, DC: Population Council. \\ Version of record: https://doi.org/10.1177/003335491012500222
}

This Report is brought to you for free and open access by the Population Council. 


\section{LOOKING BACK, MOVING FORWARd}

\section{Understanding the HIV RISK AND Sexual Health Needs of Men Who Have Sex With Men}

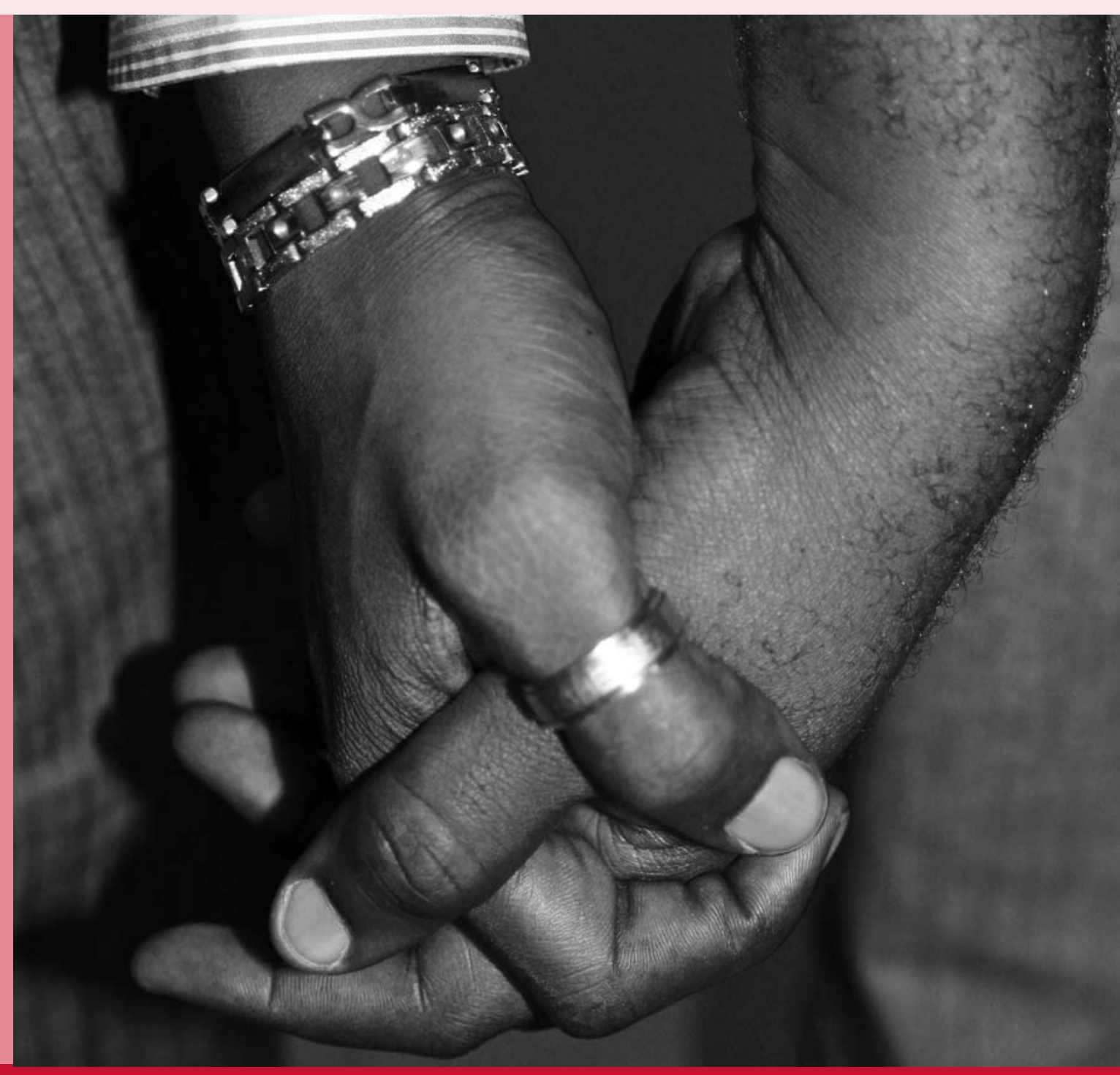

HORIZONS StUdIES 2001 to 2008 


\section{Hgrizons}

In 1997, the Population Council initiated the Horizons Program—a decade-long USAID-funded collaboration with the International Center for Research on Women, the International HIV/AIDS Alliance, PATH, Tulane University, Family Health International, and Johns Hopkins University—designing, implementing, evaluating, and expanding innovative strategies for HIV prevention and care.

Horizons developed and tested ways to optimize HIV prevention, care, and treatment programs; worked to reduce stigma and improve gender-biased behaviors; and greatly expanded knowledge about the best ways to support, protect, and treat children affected by HIV and AIDS. In all its projects, Horizons strengthened the capacity of local institutions by providing support and training to colleagues.

This series of synthesis papers presents lessons learned and best practices on six key topics that Horizons investigated: HIV-related stigma, access to antiretroviral therapy, men who have sex with men, orphans and vulnerable children, HIV and gender, and prevention of mother-to-child transmission of HIV. 


\section{Understanding the HIV RISK AND Sexual Health Needs of Men Who Have Sex With Men}

Around the world, men who have sex with men (MSM) face stigma and discrimination. The stigma attached to male-to-male sexual behavior hinders men from seeking appropriate health care and counseling that might reduce their risk of HIV infection and results in programs and policies that do not address the needs of MSM. Horizons approached this situation using innovative techniques for finding and interviewing MSM about their experiences in Africa and South America. While the lives of MSM in these settings are different, Horizons results highlighted HIV vulnerabilities across all the studies. The Population Council and its Horizons Program researchers were among the first to document and characterize the population of MSM in Africa, a crucial first step in developing appropriate programs for them. Findings suggested increasing outreach via peer educators and sensitizing service providers and counselors to the specific medical and prevention needs of MSM.

\section{Introduction}

From the beginning of the HIV epidemic, unprotected anal intercourse has been recognized as a primary risk factor for HIV and sexually transmitted infections (STIs). HIV prevention, counseling, and testing are cornerstones for HIV programs serving men who have sex with men (MSM) in the developed world, and most HIV-related behavioral research among MSM has been conducted in North America and Europe [1]. Limited research in developing countries includes assessments and evaluations of these men and their HIV risk in Latin America and the Caribbean [2-8] and Asia [9-11].
In Africa, however, there has been a profound absence of any policy, program, or research initiative that assessed MSM as a vulnerable population or considered them as a distinct sub-population. Since the first appearance of HIV on the continent, most African policies dealing with HIV and AIDS were based on the belief that unprotected heterosexual contact was the primary driver of the African epidemic [12-14]. This was a key factor in convincing African policymakers of the severity of the epidemic, nearly all HIV prevention programs in Africa have focused exclusively on the risks associated with vaginal intercourse. ${ }^{1}$

\footnotetext{
${ }^{1}$ South Africa was one exception, where its post-apartheid Constitution provided legal protection to homosexuals and empowered some grassroots HIV prevention initiatives.
} 
In the late 1990s, African heads of states Daniel arap Moi of Kenya and Robert Mugabe of Zimbabwe both publicly denied that indigenous homosexuality or same-sex sexual behavior existed in Africa without coercion through Western or foreign influence [15]. Such prominent public statements reflect a deeply entrenched culture of homophobia that persists today. Recent opinion articles in African newspapers state that same-sex sexualities "have been non-African since time immemorial [16]," and they "violate the cultural, religious, moral, and legal norms of the country [17]."

The denial of sexual interactions between men, and the stigma associated with it, discouraged African researchers from objectively evaluating homosexuality for fear that others would ridicule them and question their own sexual orientation [18]. Prior to 2000, research on MSM in Africa was limited to occasional ethnographic or qualitative studies [19-21], but there were no population-based surveys or assessments that attempted to quantify and characterize them as a sub-population within African social structures, let alone to assess or survey their sexual behaviors and exposure to STIs.

However, limited qualitative documentation as well as an abundance of anecdotal evidence suggested that MSM are present in Africa and likely are at increased risk for HIV, but are largely invisible from researchers and policy makers. Given this discrepancy, the Horizons Program expanded its portfolio to investigate the vulnerability of these men in Africa, first through descriptive assessments, then followed by intervention studies in Senegal and Kenya.

In contrast to Africa, the populations of MSM in Latin America have experienced different challenges. While targeted homophobia and discrimination is still an essential problem in the region, the institutional denial does not exist in the same form as seen in Africa. The distinction is important as it affected the strategy for developing a research portfolio on either continent. In Africa it was determined that it was most important to implement studies to describe and characterize the population as a way to convince policy makers that MSM did indeed exist. While in Latin America, the Horizons program needed to focus on analysis of behaviors among MSM in order to develop new evidence-based approaches to risk-reduction and to guide prevention programs. Horizons' nearly decade long program on MSM in Africa and Latin America is summarized below, including research methodologies, study findings, and program evaluations. The summary includes future directions and approaches for HIV research among MSM in developing countries.

\section{Using Innovative Research Strategies to Identify a Hard-to-Reach Population}

Horizons and partners designed, conducted, and published the first large-scale descriptive studies of African MSM in 2001 in Dakar, Senegal [22] and in 2004 in Nairobi, Kenya [23]. Both studies used quantitative survey methods as well as in-depth interviews and ethnographic observations. These studies documented the existence of MSM within major African cities, previously unknown to national AIDS programs, as well as risk behaviors that rendered these populations especially vulnerable to HIV. Following the success of these assessments, Horizons and regional partners expanded the research agenda to include an intervention study of MSM in Senegal and of male sex workers who have sex with men in Mombasa, Kenya [24]. The latter study used capture-recapture methods to determine the number of active male sex workers, estimated at 700 in Mombasa alone [25].

Entrenched homophobia makes identifying MSM a particularly challenging task. The Horizons studies used three sampling strategies 
to recruit MSM. Snowball sampling, in which participants randomly recruit peers from their personal networks, was used in the Dakar and Nairobi studies. Snowball sampling, however, is a non-probability sampling method, which may fail to reach some MSM and produce biased results [28].

In its Latin American studies, Horizons and partners incorporated recent innovations in probability sampling for MSM, as well as HIV testing of the study population to produce HIV prevalence estimates. A study was conducted in the southeastern city of Campinas, Braxzil [26]. In Paraguay, MSM were enrolled for a study in Ciudad del Este, a city on the border of Brazil and Argentina with a large concentration of high-risk populations such as truck drivers, drug users, and sex workers (Figure 1) [27].
The two Latin American studies used respondent-driven sampling (RDS), a more rigorous methodology similar to snowball sampling that uses more controlled peer recruitment and statistical weights to provide theoretically unbiased population estimates [29-32]. RDS has been successful in recruiting MSM in previous studies in other settings [33-35], including Kampala [36] and Zanzibar [37] in Africa, establishing the method as feasible and preferable to snowball sampling. Despite the advantages of RDS, recruitment of MSM proved challenging in the Latin American studies, though this appeared to be related to fears of disclosure and testing for HIV rather than to the methodology itself. Nevertheless, these studies are the first to provide population estimates for HIV prevalence and associated risk behaviors amongst MSM in Brazil and Paraguay, and led to the adoption of RDS for

\section{Figure 1 Recruitment pattern of MSM who engaged in sex work in the last six months and MSM who did not in Ciudad del Este, Paraguay $(n=296)$}

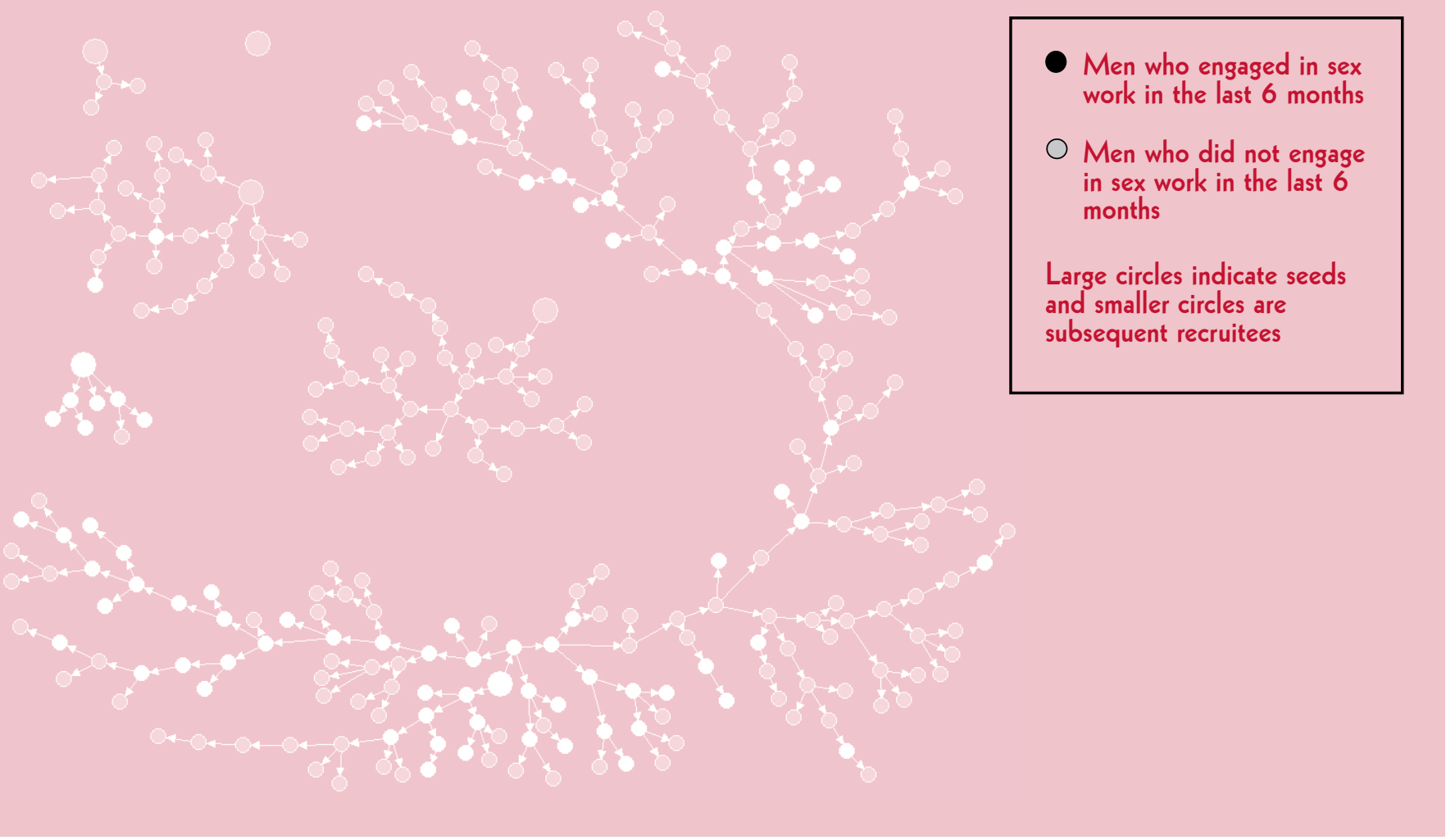

This figure compares the recruitment pattern of men who engaged in sex work in the last six months and those who did not. This figure illustrates the high tendency for in-group recruitment, especially in the group not involved in sex work. 
the national surveillance of high-risk populations in Brazil.

Time-location sampling, in which participants are sampled from a list of contact locations and the times in which they are found at these venues, was used to sample male sex workers in Mombasa. First, Horizons and partners implemented a capture-recapture count of male sex workers who sell sex to men [25], which produced detailed data on locations and times where male sex workers were seeking clients. This data was used to produce the time-location sampling frame. Research staff avoided public scrutiny by training MSM as "mobilizers" to identify male sex workers at these locations and escort them to a central location for interviewing. These methodologies were effective in Mombasa, but further study is needed to compare the generalizability and reliability of time-location versus RDS sampling among male sex worker populations.

\section{Enlisting help from local partners}

The African studies benefitted from partnerships with anthropologists from respected local collaborating institutions in Senegal (Cheikh Anta Diop University) and Kenya (University of Nairobi), who helped formulate research topics and questions, provided enty points into communities, and supplemented the quantitative behavioral surveys with in-depth interviews and ethnographic observations. These partnerships proved critical in establishing the legitimacy of the research in Africa and provided a foundation for future partnerships with government agencies in both countries.

\section{HIV and STI Risk Among MSM}

\section{Sexual risk behaviors and networks}

While the experience and realities of MSM in Africa and Latin America were different, results highlighted HIV vulnerabilities across all the

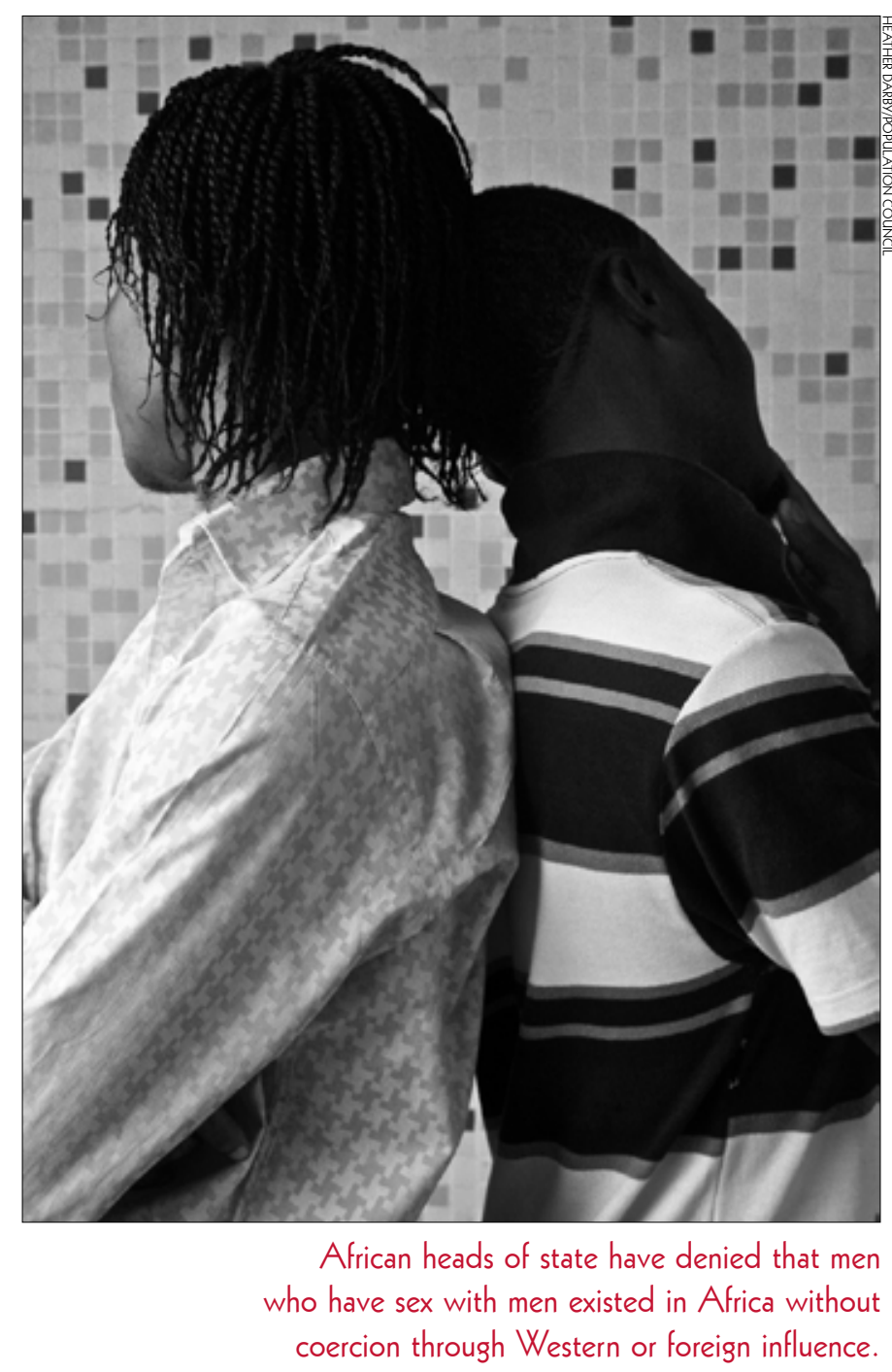

Horizons studies. Table 1 summarizes the population characteristics and reported sexual behaviors of the six MSM studies described in this paper. In the African studies, high levels of insertive and receptive anal sex with inconsistent condom use were the norm. High proportions of multiple or concurrent sex partners were reported in all studies, but were particularly high among Mombasa male sex workers and MSM in Nairobi, Campinas, and Ciudad del Este.

Reported condom use varied widely across studies. The 2001 assessment of MSM in Dakar found low levels of condom use with last male insertive partners (23 percent) and receptive partners (14 percent). Follow-up surveys 


\section{Table 1 Sample characteristics, sexual behaviors, and HIV prevalence of study or comparable populations}

\begin{tabular}{|c|c|c|c|c|c|c|}
\hline & \multicolumn{2}{|c|}{ Senegal } & \multicolumn{2}{|c|}{ Kenya } & \multirow{2}{*}{$\frac{\text { Brazil }}{\text { Campinas }^{a}}$} & \multirow{2}{*}{$\begin{array}{c}\text { Paraguay } \\
\begin{array}{c}\text { Ciudad del } \\
\text { Este }^{\mathrm{a}}\end{array}\end{array}$} \\
\hline & Dakar & Dakar & Nairobi & Mombasa & & \\
\hline \multicolumn{7}{|l|}{ Sample characteristics } \\
\hline Year of survey & 2001 & $2003 / 2005$ & 2004 & 2006 & 2005-2006 & 2006 \\
\hline Target population & $\begin{array}{l}M S M \geq \\
\text { years }\end{array}$ & $\begin{array}{c}M S M \\
\text { years }\end{array}$ & $\begin{array}{c}M S M \\
\text { years }\end{array}$ & $\begin{array}{c}\text { Male sex } \\
\text { workers } \geq 16 \\
\text { years }\end{array}$ & $\begin{array}{l}M S M \geq 14 \\
\text { years }\end{array}$ & $\begin{array}{c}M S M \\
\text { years }\end{array}$ \\
\hline Sample size & 250 & $258 / 290$ & 500 & 425 & 658 & 296 \\
\hline Type of study & Descriptive & Intervention & Descriptive & Intervention ${ }^{b}$ & Descriptive & Descriptive \\
\hline Sampling methodology & Snowball & Snowball & Snowball & $\begin{array}{l}\text { Time- } \\
\text { location }\end{array}$ & RDS & RDS \\
\hline $\begin{array}{l}\text { Mean [median] age of men in } \\
\text { sample }\end{array}$ & 25 & $27 / 26$ & 26 & 26 & {$[23]$} & {$[21]$} \\
\hline \multicolumn{7}{|l|}{ Sexual behaviors } \\
\hline $\begin{array}{l}\text { Consistent condom use with } \\
\text { male partner (percent, time } \\
\text { period) }\end{array}$ & $\begin{array}{c}27 \text { percent } \\
\text { past } 1 \text { month }\end{array}$ & $\begin{array}{l}52 \text { percent/ } \\
58 \text { percent, } \\
\text { past } 12 \\
\text { months }\end{array}$ & $\begin{array}{l}56 \text { percent, } \\
\text { past } 12 \\
\text { months }\end{array}$ & $\begin{array}{l}36 \text { percent, } \\
\text { past } 30 \text { days }\end{array}$ & $\begin{array}{l}29 \text { percent } \\
(I A I), 25 \\
\text { percent (RAI), } \\
\text { past } 2 \text { months }\end{array}$ & $\begin{array}{l}20 \text { percent } \\
(I A I), 35 \\
\text { percent }(\mathrm{RAI}) \text {, } \\
\text { past } 6 \text { months }^{c}\end{array}$ \\
\hline $\begin{array}{l}\text { Condom use at last sex with a } \\
\text { male partner }\end{array}$ & $\begin{array}{c}23 \text { percent } \\
(I A I), 14 \\
\text { percent (RAI) }\end{array}$ & $\begin{array}{l}73 \text { percent/ } \\
82 \text { percent }\end{array}$ & 75 percent & 58 percent & NR & NR \\
\hline $\begin{array}{l}\text { Had recent multiple male } \\
\text { partners (time period) }\end{array}$ & $\begin{array}{l}21 \text { percent, } \\
\text { past } 1 \text { month }\end{array}$ & $\begin{array}{l}26 \text { percent/ } \\
27 \text { percent, } \\
\text { past } 1 \text { month }\end{array}$ & $\begin{array}{l}47 \text { percent, } \\
\text { past } 1 \text { month }\end{array}$ & $\begin{array}{l}74 \text { percent, } \\
\text { past } 7 \text { days }\end{array}$ & $\begin{array}{l}53 \text { percent, } \\
\text { past two } \\
\text { months }\end{array}$ & $\begin{array}{l}62 \text { percent, } \\
\text { past } 6 \text { months }\end{array}$ \\
\hline $\begin{array}{l}\text { Had recent female sexual } \\
\text { partners (time period) }\end{array}$ & $\begin{array}{l}47 \text { percent, } \\
\text { past } 1 \text { month }\end{array}$ & $\begin{array}{c}9 \text { percent/ } \\
12 \text { percent, } \\
\text { past } 1 \text { month }\end{array}$ & $\begin{array}{l}5 \text { percent, } \\
\text { past } 1 \text { month }\end{array}$ & $\begin{array}{l}30 \text { percent, } \\
\text { past } 30 \text { days }\end{array}$ & $\begin{array}{l}16 \text { percent, } \\
\text { past } 2 \text { months }\end{array}$ & $\begin{array}{l}83 \text { percent, } \\
\text { past } 6 \text { months }\end{array}$ \\
\hline $\begin{array}{l}\text { Received money for sex with a } \\
\text { man (time period) }\end{array}$ & $\begin{array}{l}9 \text { percent, last } \\
\text { sex with man }\end{array}$ & $\begin{array}{l}26 \text { percent/ } \\
17 \text { percent, } \\
\text { past } 1 \text { month }\end{array}$ & $\begin{array}{l}52 \text { percent, } \\
\text { past } 12 \\
\text { months }\end{array}$ & $\begin{array}{l}87 \text { percent, } \\
\text { past } 7 \text { days }\end{array}$ & $\begin{array}{l}15 \text { percent, } \\
\text { past } 2 \text { months }\end{array}$ & 21 percent $^{d}$ \\
\hline \multicolumn{7}{|l|}{ HIV prevalence among MSM } \\
\hline $\begin{array}{l}\text { HIV prevalence among } \\
\text { study population }\end{array}$ & NA & $\begin{array}{c}33 \text { percent } \\
(n=263)^{e, 38}\end{array}$ & NA & NA & 7 percent & 1 percent \\
\hline $\begin{array}{l}\text { HIV prevalence among } \\
\text { comparable population }\end{array}$ & $\begin{array}{l}22 \text { percent } \\
(n=465)^{39}\end{array}$ & NA & $\begin{array}{c}11 \text { percent } \\
(n=780)^{40}\end{array}$ & $\begin{array}{l}25 \text { percent } \\
(n=285)^{41}\end{array}$ & NA & NA \\
\hline $\begin{array}{l}\text { National HIV prevalence } \\
\text { among all adults age 15-49 }\end{array}$ & \multicolumn{2}{|c|}{1 percent $^{38}$} & \multicolumn{2}{|c|}{6 percent $^{38}$} & 1 percent $^{38}$ & $<1$ percent $^{38}$ \\
\hline
\end{tabular}

Note: RDS, Respondent-driven sampling; IAI, Insertive anal intercourse; RAI, Receptive anal intercourse; NR, Not reported.

RDS population estimates are presented for Brazil and Paraguay.

'Follow-up survey and evaluation planned for 2008.

'Consistent condom use is reported for IAI and RAI with occasional male partners, defined as partners with whom the respondent had sex only once or from time to time and with whom he did not exchange money, drugs, or gifts for sex.

"MSM were asked whether they "currently" engage in sex work (i.e., receiving money, drugs, or gifts in exchange for anal or oral sex). The majority indicated they sold sex to male partners.

'Among 263 men requesting HIV testing as part of study intervention. 
in Dakar in 2003 and 2005, and in Nairobi in 2004, documented condom use at last sex at more than 70 percent. Consistent condom use (considered a more important indicator in terms of HIV risk reduction [42, 43]) was reported by more than 50 percent of respondents in these surveys, but by only 36 percent of male sex workers in Mombasa and less than 30 percent in Campinas and Ciudad del Este.

Qualitative interviews with MSM in Senegal and Kenya revealed that the majority of their male sexual partners were from the same communities, and that first sexual experiences with men often took place during adolescence with friends or acquaintances. Such results refuted prevailing beliefs in Africa that homosexual behavior was the result of foreign coercion.

The prevalence of men selling sex to other men was surprisingly high in all areas studied. In addition to the Mombasa survey that specifically targeted male sex workers, the 2001 Dakar study documented that 9 percent of respondents reported selling sex to their last male partner; 15 percent of MSM in Campinas reported selling sex to men in the past two months; 21 percent of MSM in Ciudad del Este reported currently selling sex (primarily to male clients); and more than half of MSM in Nairobi reported selling sex to men in the past year. These high numbers of commercial sex workers may be a product of peer recruitment survey methods failing to reach more hidden or isolated segments of the MSM population-an area meriting further study.

These studies also demonstrate that heterosexual sex is common among MSM: 30 percent of male sex workers in Mombasa reported having a female paying or non-paying sex partner in the past 30 days; 83 percent of MSM in Ciudad del Este had a female sex partner in the past six months; 88 percent of respondents in Senegal reported ever having sex with a women; and 5 percent of MSM in Nairobi and 16 percent in Campinas reported having female sex partners in the one and two months, respectively, prior to the survey. These results underscore the fact that MSM are not sexually isolated, and that potential "bridging" of homosexual and heterosexual populations by these men have broader public health implications.

\section{HIV prevalence among MSM}

HIV testing revealed that prevalence was marginally higher than general population rates in Ciudad del Este, but much higher in Campinas. In addition, more than 70 percent of those testing positive were unaware of their status, suggesting the need to emphasize HIV testing in this group. HIV prevention programs for younger MSM are particularly importantthe Campinas study found an HIV prevalence of 4 percent among MSM between 14 and 19 years, a particularly alarming finding given that the national prevalence is 0.6 percent, and the average age of sexual debut was 13 .

Disparities are even more alarming in African HIV prevalence studies from Horizons and other sources. In Senegal, where the national prevalence is 1 percent [44], HIV prevalence among MSM ranges from 22 percent [39] among a national snowball sample to 33 percent among MSM tested during the second Dakar study [38]. In Kenya, where national prevalence is 6 percent [44], HIV prevalence among MSM ranges from 11 percent among those tested in voluntary counseling and testing (VCT) clinics [40], to 25 percent among a convenience sample of 285 MSM enrolled in a vaccine trial cohort near Mombasa [41].

\section{Stigma, discrimination, and violence: barriers to counseling, testing, and treatment}

Horizons documented a high level of physical, verbal, and sexual victimization of MSM. In addition, victims of abuse were unlikely to report incidents to the authorities. For example, in Campinas, more than 30 percent of MSM experienced physical abuse in their 
lifetime, but only 6 percent reported these incidents to authorities, and only 11 percent sought medical treatment. Additionally, 78 percent reported psychological abuse, which was found to be independently associated with unprotected receptive anal intercourse ${ }^{2}$. In Nairobi, male sex workers were significantly more likely to experience physical, sexual, and verbal abuse than other MSM (Figure 2).

Fear of public exposure prompted MSM to identify confidentiality as the most important consideration when seeking STI treatment or HIV counseling. At the same time, qualitative data revealed that MSM often feared revealing their sexual identity and behaviors to health care providers. In addition, in-depth interviews with health care providers in Nairobi showed that counselors and providers generally did not ask about same-sex sexual behavior, and thus did not offer appropriate HIV prevention messages.

\section{Use of condom-damaging oil-based lubricants}

All of the Horizons studies dealing with MSM in Africa documented frequent use of petroleum jelly, baby oils, lotions, and other

${ }^{2}$ Adjusted odds ratio: 1.89; $\mathrm{p}<0.05$ oil-based lubricants during anal intercourse both with and without condoms. Respondents in the Senegal study reported using products such as Vaseline ${ }^{\oplus}$ (34 percent), shea butter (21 percent), body lotion (19 percent), shaving gels or creams (9 percent), and butter/cooking oil (3 percent). Only 26 percent of MSM in Nairobi and 21 percent of male sex workers in Mombasa correctly knew that water-based lubricants should be used with latex condoms, and 15 percent of male sex workers had used a water-based lubricant with their last male client.

In both Kenyan studies, reported use of oilbased lubricants was significantly associated with ever experiencing condom breakage, consistent with studies documenting decreased structural integrity of condoms when used with lubricants containing mineral or vegetable oils [45-47]. Finally, respondents consider condoms to be available and affordable, while water-based lubricants are scarce and costly. In Nairobi and Mombasa, for example, waterbased lubricants are only available in select supermarkets and pharmacies, where a $50 \mathrm{~g}$ tube of KY Jelly ${ }^{\oplus}$ costs approximately US $\$ 4.00$ compared to US $\$ 0.30$ for a $25 \mathrm{~g}$ container of petroleum jelly.

The Horizons study in Paraguay found that lubricant use was low in Ciudad del Este, with 28 percent using lubricants during insertive anal intercourse and 16 percent during receptive anal intercourse. Among lubricant users, only half reported using water-based lubricants.

\section{Sensitizing Counselors to the Needs of MSM}

Findings from early Horizons studies led to recommenda- 
tions for increasing outreach via peer educators and training service providers and counselors on, or sensitizing them to, the specific medical and prevention needs of MSM. In Dakar, partners trained $40 \mathrm{MSM}$ as peer educators and recruited 12 service providers to provide MSMsensitive services with subsequent increases in HIV testing and consistent condom use among MSM.

In Mombasa, 40 male sex workers who are peer educators were trained in HIV prevention and basic counseling skills. Over 1,900 MSM and male sex worker peers were reached in the first year of operation. Additionally, 20 health care providers from Mombasa-area hospitals and clinics were trained and sensitized to MSM issues including diagnosis of STIs and HIV counseling. At the drop-in-center, 1,231 clients ( 823 male, 408 female) were counselled and tested for HIV. Condoms and water-based lubricants were distributed at the drop-in centre and by peer educators with substantial uptake of both education sessions and dropin-center visits. Over 2 million male condoms were distributed.

These approaches were successful in providing HIV prevention resources to MSM in highly stigmatized societies. In addition, other intervention models, including modified HIV counseling and testing for MSM, are being delivered in Nairobi. These pilot projects, however, remain model programs and have yet to be adopted more broadly throughout Africa.

\section{Future Research and Next Steps}

The Horizons studies greatly expanded our understanding of the types and prevalance of high risk behaviors among MSM in developing countries; behaviors that are likely contributing significantly to the HIV epidemic. Horizons research used innovative quantitative and qualitative sampling methodologies and produced the first large-scale assessments of MSM in Africa. The Population Council, which directed the Horizons Program, has been credited as "the first international NGO to recognize that the HIV-related vulnerabilities of MSM in Africa deserved serious attention [48]."

Currently, research on MSM in Africa is expanding beyond the Horizons Program. Published HIV prevalence studies exist for Senegal [39] and Kenya [41], as well as a behavioral study for Kampala, Uganda [36]. An assessment of MSM risk was completed in Johannesburg, South Africa [49], and recent RDS behavioral surveys in Zanzibar [37] and Lusaka, Zambia [50], are either being conducted or analyzed. This growing collection of research activities will shed light on a number of the HIV vulnerabilities of MSM in subSaharan Africa [51].

At the policy level, while Brazil has included MSM as a priority group in its national HIV prevention campaigns, most national HIV programs in Africa have been slow to acknowledge and address MSM in official policy. Only

\section{"The clinic is in a discreet location and the medical officers are very kind and available to attend to us...if we had been mistreated, it is obvious that we would not have returned. We are very much wel- comed and made to feel comfortable. We receive counseling which is very vital to us because it is directly related to our activities. We also obtain condoms and lubricants to better protect ourselves from diseas- es. Honestly speaking, all the medical officers there are exemplary."




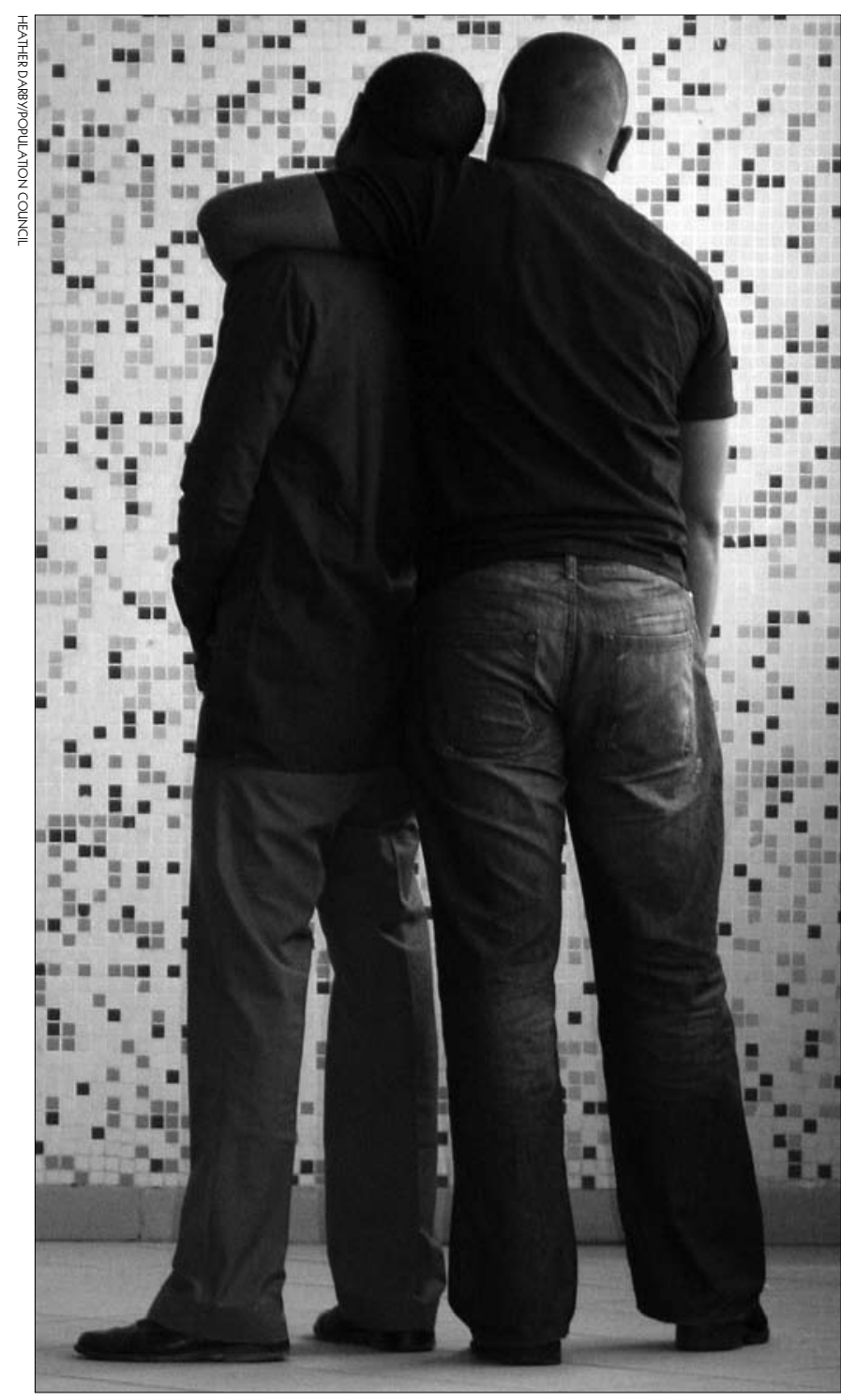

Horizons studies have added to the general knowledge of MSM in developing countries, including the first large-scale assessments of MSM in Africa, through the use of innovative quantitative and qualitative sampling methodologies.

a few African countries mention MSM in their National Strategic Plans, and few have a specific national HIV policy for MSM. Many service providers are reluctant to officially provide services to MSM until these policy issues are addressed, and many researchers continue to avoid study of MSM for fear of stigma. In addition, stigma from community and religious groups remains a barrier to implementation of service delivery and research initiatives, although there has been increased public dis- cussion of the issue in some countries. Even simple measures, such as consistent provision of water-based lubricant, have yet to be adopted in many countries, although further study on the epidemiological impact of lubrication use and condom breakage is needed.

MSM in developing countries continue to be both "understudied and underserved [52]," but the best way to influence policy is through provision of unbiased data. The work outlined here has already resulted in some movement: the directors of the National AIDS Commission in Senegal [53] and National AIDS Control Council in Kenya [54] have since acknowledged the existence of MSM and the need to address them in national HIV policy. In addition, the Population Council and Kenya's National AIDS Control Council held a regional conference on MSM for African policymakers, including directors of National AIDS Control Programs in $2008^{3}$. The meeting concluded with a draft consensus statement recommending that national HIV programs implement programs that are inclusive of MSM and empower African health service providers to serve MSM; support research activities that inform government policy and HIV prevention and treatment programs for MSM; develop strategies to build the capacity of the MSM community and increase public understanding of MSM; and increase the involvement of MSM in all aspects of program development and implementation. By gathering those most influential in terms of designing policy, and presenting the state of the science, the Population Council hopes to have a broad and lasting effect on provision of HIV prevention services to this population. The Council also urges other organizations to expand their efforts towards understanding and addressing the HIV risks of MSM in developing countries.

\footnotetext{
${ }^{3}$ The meeting report, "The overlooked epidemic: Addressing HIV prevention and treatment among men who have sex with men in sub-Saharan Africa, report of a consultation, Nairobi, Kenya, 14-15 May 2008," is available on the Population Council website at http://www.popcouncil.org/ pdfs/HIV_KenyaMSMMeetingReport.pdf.
} 


\section{References}

1. R. D. Stall et al., "The gay '90s: a review of research in the 1990s on sexual behavior and HIV risk among men who have sex with men," AIDS 14 (Suppl 3): S101S114 (2000).

2. C. F. Caceres, "HIV among gay and other men who have sex with men in Latin America and the Caribbean: a hidden epidemic?," AIDS 16 (suppl 3): S23-S33 (2002).

3. J. Ramirez et al., "AIDS knowledge and sexual behavior among Mexican gay and bisexual men," AIDS Education and Prevention 6 (2): 163-174 (1994).

4. M. A. Zimmerman et al., "An HIV/AIDS prevention project for Mexican homosexual men: an empowerment approach," Health Education and Behavior 24 (2): 177-190 (1997).

5. L. R. Kerr-Pontes et al., "Self-reported sexual behaviour and HIV risk taking among men who have sex with men in Fortaleza, Brazil," AIDS 13 (6): 709-717 (1999).

6. L. H. Harrison et al., "Incident HIV infection in a high-risk, homosexual, male cohort in Rio de Janeiro, Brazil," Journal of Acquired Immune Deficiency Syndromes 21 (5): 408-412 (1999).

7. M. Carneiro et al., "Design, implementation, and evaluation at entry of a prospective cohort study of homosexual and bisexual HIV-1-negative men in Belo Horizonte, Brazil: Project Horizonte," Journal of Acquired Immune Deficiency Syndromes 25 (2): 182-187 (2000).

8. S. R. Tabet et al., "Sexual behaviors and risk factors for HIV infection among men who have sex with men in the Dominican Republic," AIDS 10 (2): 201-206 (1996).

9. C. Beyrer et al., "Same-sex behavior, sexually transmitted diseases and HIV risks among young northern Thai men," AIDS 9 (2): 171-176 (1995).

10. P. Girault et al., "Sexual behavior, STIs and HIV among men who have sex with men in Phnom Penh, Cambodia, 2000" (Phnom Penh: Family Health International, 2002).

11. B. Zhang et al., "A survey of men who have sex with men: mainland China," American Journal of Public Health 90 (12): 1949-1950 (2000).

12. M. Melbye et al., "Evidence for heterosexual transmission and clinical manifestations of human immunodeficiency virus infection and related conditions in Lusaka, Zambia," Lancet 2 (8516): 1113-1115 (1986).

13. A. R. Ronald et al., "A review of HIV-1 in Africa," Bulletin of the New York Academy of Medicine 64 (6): 480-490 (1988).
14. D. J. Hunter, "AIDS in sub-Saharan Africa: the epidemiology of heterosexual transmission and the prospects for prevention," Epidemiology 4 (1): 63-72 (1993).

15. M. Engelke, "'We wondered what human rights he was talking about': Human rights, homosexuality and the Zimbabwe International Book Fair," Critique of Anthropology 19 (3): 289-314 (1999).

16. H. J. Nyamu, "Gays have no business fighting for recognition in Kenya," Daily Nation (Nairobi), September 28 2007, sec. 1, p. 11.

17. M. Nkangi, "Govt must tighten screws on gays, lesbians," Daily Monitor (Kampala), November 28 2007, sec. 1, p. 12.

18. P. Tapsoba et al., "What kept away African professionals from studying MSM and addressing their needs in Africa? Challenges and obstacles" (poster presented at XV International AIDS Conference, Bangkok, Thailand, July 2004).

19. N. Teunis, "Homosexuality in Dakar: Is the bed the heart of a sexual subculture," Journal of Gay, Lesbian and Bisexual Identity 1 (2): 153-169 (1996).

20. N. McKenna, On the Margins: Men Who Have Sex with Men and HIV in the Developing World (London: Panos Institute, 1996).

21. W. Roscoe and S. O. Murray, Boy-Wives and Female Husbands: Studies in African Homosexualities (New York: PALGRAVE, 1998).

22. C. I. Niang et al., "'It's raining stones': stigma, violence and HIV vulnerability among men who have sex with men in Dakar, Senegal," Culture, Health and Sexuality 5 (6): 499-512 (2003).

23. W. Onyango-Ouma, H. Birungi, S. Geibel, "Understanding the HIV/STI risks and prevention needs of men who have sex with men in Nairobi, Kenya," Horizons Final Report (Washington, DC: Population Council, 2005).

24. S. Geibel et al., "Improving HIV programs for men who sell sex to men in Mombasa, Kenya" (paper presented at the 2007 HIV/AIDS Implementers' Meeting, Kigali, Rwanda, June 2007).

25. S. Geibel et al., "'Are you on the market?': a capture-recapture enumeration of men who sell sex to men in and around Mombasa, Kenya," AIDS 21 (10): 1349-1354 (2007).

26. M. de Mello et al., "Assessment of risk factors for HIV infection among men who have sex with men population in the metropolitan area of Campinas city, Brazil, using respondent-driven sampling," Horizons Final Report (Washington, DC: Population Council, 2008). 
27. M. Chinaglia et al., "Assessment of risk factors for HIV infection in female sex workers and men who have sex with men at the triple-border area of Ciudad del Este, Paraguay," Horizons Final Report (Washington, DC: Population Council, 2008).

28. R. Magnani et al., "Review of sampling hard-to-reach and hidden populations for HIV surveillance," AIDS 19 (Suppl 2): S67-S72 (2005).

29. D. D. Heckathorn, "Respondent-driven sampling: A new approach to the study of hidden populations," Social Problems 44 (2): 174-199 (1997).

30. A. S. Abdul-Quader et al., "Implementation and analysis of respondent driven sampling: Lessons learned from the field," Journal of Urban Health 83 (6 Suppl): i1-i5 (2006).

31. D. D. Heckathorn, "Respondent-driven sampling II: Deriving valid population estimates from chain-referral samples of hidden populations," Social Problems 49 (1): 11-34 (2002).

32. M. J. Salganik, "Variance estimation, design effects, and sample size calculations for respondent-driven sampling," Journal of Urban Health 83 (6 Suppl): i98-i112 (2006).

33. J. Ramirez-Valles et al., "From networks to populations: the development and application of respondent-driven sampling among IDUs and Latino gay men," AIDS and Behavior 9 (4): 387-402 (2005).

34. A. S. Abdul-Quader et al., "Effectiveness of respondentdriven sampling for recruiting drug users in New York City: findings from a pilot study," Journal of Urban Health 83 (3): 459-476 (2006).

35. W. Yeka et al., "Application of respondent driven sampling to collect baseline data on FSWs and MSM for HIV risk reduction interventions in two urban centres in Papua New Guinea," Journal of Urban Health (83) (6 Suppl): i60-i72 (2006).

36. P. Kajubi et al., "Gay and bisexual men in Kampala, Uganda," AIDS and Behavior 12 (3): 492-504 (2008).

37. M. Dahoma et al., "Experience implementing RDS methodology for MSM in Zanzibar" (paper presented at 2007 HIV/AIDS Implementers' Meeting, Kigali, Rwanda, June 2007).

38. Social Hygiene Institute, "MSM intervention statistics" (Population Council, unpublished report, 2006).

39. A. S. Wade et al., "HIV infection and sexually transmitted infections among men who have sex with men in Senegal," AIDS 19 (18): 2133-2140 (2005).

40. P. Angala et al., "Men who have sex with men (MSM) as presented in VCT data in Kenya" (poster presented at XVI International AIDS Conference, Toronto, Canada, August 2006).

41. E. J. Sanders et al., "HIV-1 infection in high risk men who have sex with men in Mombasa, Kenya," AIDS 21 (18): 2513-2520 (2007).

42. S. D. Pinkerton, P. R. Abramson, "Effectiveness of condoms in preventing HIV transmission," Social Science and Medicine 44 (9): 1303-1312 (1997).

43. K. R. Davis, S. C. Weller, "The effectiveness of condoms in preventing heterosexual HIV transmission," Family Planning Perspectives 31 (6): 272-279 (1999).
44. UNAIDS, "2006 report on the global AIDS epidemic" (Geneva: UNAIDS, 2006).

45. B. Voeller et al., "Mineral oil lubricants cause rapid deterioration of latex condoms," Contraception 39 (1): 95-102 (1989).

46. A. D. Rosen, T. Rosen, "Study of condom integrity after brief exposure to over-the-counter vaginal preparations," The Southern Medical Journal 92 (3): 305-307 (1999).

47. M. Steiner et al., "The impact of lubricants on latex condoms during vaginal intercourse," International Journal of STD \& AIDS 5 (1): 29-36 (1994).

48. C. A. Johnson, Off the Map: How HIVIAIDS Programming is Failing Same-sex Practicing People in Africa (New York: International Gay and Lesbian Human Rights Commission, 2007).

49. T. Lane et al., "HIV risk behaviours among black MSM in Johannesburg, South Africa" (poster presented at XV International AIDS Conference, Bangkok, Thailand, July 2004).

50. Mansergh, Gordon, personal communication

51. A. Smith et al., "Men who have sex with men and HIV/AIDS in sub-Saharan Africa," Lancet 374(9687): 416-422 (2009).

52. S. Baral et al., "Elevated risk for HIV infection among men who have sex with men in low- and middle income countries 2000-2006: A systematic review," PLoS Medicine 4 (12): e339 (2007).

53. Ibra Ndoye, "L'expérience sénégalaise : quelles leçons à partager?" (welcome address at the Third Social Aspects of HIV/AIDS Research Alliance Conference, Dakar, Senegal, 10 October 2005).

54. Orago, Alloys, personal communication. 


\section{ACKNOWLEDGMENTS}

The Horizons MSM studies presented in this paper were conducted in partnership or collaboration with several institutions and individuals, and would not have been successful without their substantial effort and contributions. The authors extend special thanks to the co-primary investigators for these studies and their affiliated partner institutions: Cheikh Niang, Institut des Sciences de I'Environnement, faculté des Sciences, Université Cheikh Anta Diop, Senegal; Amadou Moreau, Population Council, Senegal; W. Onyango-Ouma, Institute of African Studies, University of Nairobi; Harriet Birungi, FRONTIERS Program, Population Council, Kenya; Stanley Luchters, International Centre for Reproductive Health, Kenya; Juan Diaz, Maeve Brito de Mello, Adriana de Araujo Pinho, and Magda Chinaglia, Population Council, Brazil; Aristides Barbosa Jr., National Program of STD/ AIDS, Ministry of Health, Brazil; Suzanne Westman, Centers for Disease Control and Prevention, Brazil; Francisco Hideo Aoki , State University of Campinas, Brazil; Magdalena Insfran de Martinzez, Regional AIDS Program of Alto Parana, Paraguay. We also thank other current and former staff of the Horizons Program for their significant contributions to these studies over the years including, but not limited to, Naomi Rutenberg, Julie Pulerwitz, Chris Castle, and Ellen Weiss. Thanks to Gina Duclayan and Hena Khan for editing and Sherry Hutchinson for layout. 
Authors: Scott Geibel, Population Council, Nairobi, Kenya; Waimar Tun, Population Council, Washington, DC, USA; Placide Tapsoba, Population Council, Accra, Ghana; Scott Kellerman, Population Council, New York, New York, USA
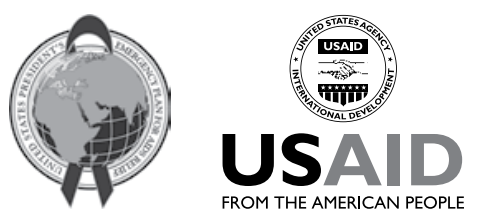

This study and final report were made possible by the President's Emergency Plan for AIDS Relief and the generous support of the American people through the United States Agency for International Development (USAID) under the terms of Cooperative Agreement No. HRNA-00-97-00012-00. The contents are the responsibility of the Horizons Program and do not necessarily reflect the views of USAID or the United States Government.

Published in April 2010.

QPopulation Council

The Population Council is an international, non-profit, nongovernmental institution that seeks to improve the well-being and reproductive health of current and future generations around the world and to help achieve a humane, equitable, and sustainable balance between people and resources. The Council conducts biomedical, social science, and public health research and helps build research capacities in developing countries. Established in 1952, the Council is governed by an international board of trustees. Its New York headquarters supports a global network of regional and country offices.

Copyright (C) 2010. The Population Council Inc.

Suggested citation: Geibel, Scott, Waimar Tun, Placide Tapsoba, and Scott Kellerman. 2010. "Looking back, moving forward: Understanding the HIV risk and sexual health needs of men who have sex with men, Horizons studies 2001 to 2008," Horizons Synthesis Background Papers. Washington, DC: Population Council.

This document may be reproduced in whole or in part without permission of the Population Council provided full source citation is given and the reproduction is not for commercial purposes. 


USAID

Population Council

HIV and AIDS Program

4301 Connecticut Ave NW, Suite 280

Washington, DC 20008

Tel: 202-237-9400

Fax: 202-237-8410

pubinfo@popcouncil.org 